\title{
Benign Female Breast Neoplasm
}

National Cancer Institute

\section{Source}

National Cancer Institute. Benign Female Breast Neoplasm. NCI Thesaurus. Code C3848.

A non-metastasizing neoplasm that arises from the breast parenchyma in females. 